\title{
Changes in elephant conservation management promote density-dependent habitat selection in the Kruger National Park
}

\author{
Ashley S. Robson ${ }^{a}$ \& Rudi J. van Aarde ${ }^{b}$
}

Conservation Ecology Research Unit, Department of Zoology and Entomology, University of Pretoria, South Africa 0002.

a ashleysrobson@gmail.com

${ }^{\mathrm{b}}$ Corresponding author: rjvaarde@ zoology.up.ac.za; +27124202753

Running title: Density-dependent habitat selection of elephants

\begin{abstract}
In conservation, adaptive management relies on the assessment of past actions to improve conservation efficiencies in the future. Recently, conservation management approaches for African elephants changed, however, little has been done to assess the effectiveness of the changes. This is a major shortcoming as elephants (and their management) have a considerable influence on other savanna species. Traditionally, the management of elephants focused on artificially manipulating numbers through culling, water supplementation and fencing. Lately, and specifically in the Kruger National Park, the focus has progressed to promoting ecological processes that may naturally regulate elephant populations. Density-dependent habitat selection - suggestive of competition for resources - is fundamental in stimulating the regulatory processes that managers expect to promote. In this paper, we evaluated how effective the changes in Kruger's elephant management approach were in promoting density-
\end{abstract}


dependent habitat selection. We used 15 years of helicopter-based surveys and resource selection functions to test our primary prediction that an increase in population density following the cessation of culling generalised dry season habitat selection by female elephants in Kruger (i.e. decreased selection of high-quality habitat and increased selection of lower quality habitat). We found that as densities increased, female occupancy of the Park rose and dry season selection of highly wooded areas that provide crucial resources for elephant survival and reproduction, weakened. Conversely, density had little effect on the selection of rivers. Rather, high dry season rainfall allowed female elephants to select areas farther from permanent water, potentially alleviating normal dry season foraging restrictions. Our novel identification of density-dependent habitat selection for elephants suggests that the change in conservation management in Kruger was effective in promoting a potential driver of population regulation. We suggest that ecological principles continue to provide an effective framework for scientific evaluation and elephant conservation management in Kruger and beyond.

Keywords aerial surveys, demography, effectiveness, Loxodonta africana, population regulation, scientific evidence 


\section{Introduction}

We need to know which conservation management approaches were effective in the past if we are to improve future endeavours (Pullin \& Knight, 2001). Ideally, we should scientifically evaluate how effective previous approaches were in reaching objectives and base future decisions on the resulting evidence (Pullin et al., 2004). By doing so, we may progress the basis for conservation management decision-making from personal opinions towards a scientific foundation (Pullin et al., 2004). Historically, subjective opinions and agricultural insights dominated conservation management approaches for African elephants Loxodonta africana (van Aarde, Jackson \& Ferreira, 2006; van Aarde \& Jackson, 2007; Young \& van Aarde, 2011). More recently, approaches changed and managers started to place ecological theory at the centre of management decisions (van Aarde \& Jackson, 2007). Although elephants are a wellstudied species (Trimble \& van Aarde, 2010), we lack comprehensive studies that examine the effectiveness of the changes in their management. This scarcity of research represents a major shortcoming in the conservation management of savanna ecosystems as elephants can have substantial influence on other species and ecological processes (Skarpe et al., 2004; O'Connor, Goodman \& Clegg, 2007; Guldemond, Purdon \& van Aarde, 2017).

Across Africa, the early management of elephants focused primarily on manipulating numbers (Pienaar \& van Niekerk, 1963; Hanks et al., 1981; Whyte, van Aarde \& Pimm, 1998). Managers supplemented water across landscapes in an attempt to increase numbers (Pienaar \& van Niekerk, 1963; Davidson, 1967; Croze \& Lindsay, 2011) and buffer populations against the possible negative effects of droughts (Pienaar, 1983). As anticipated, numbers began to rise as elephants responded demographically to the increased availability of a limiting resource (Chamaillé-Jammes et al., 2008; Shrader, Pimm \& van Aarde, 2010). In some areas, management then viewed relatively high densities as detrimental to the conservation of other species (Owen-Smith, 1996). Culling, contraception and translocation became attractive 
options to artificially reduce and stabilise elephant populations at densities lower than those dictated by locally available resources (van Aarde, Whyte \& Pimm, 1999; Kerley \& Shrader, 2007). More recently, some managers have begun to focus on ecological rather than agricultural paradigms. In these cases, managers have increased the area available to elephants by dropping fences, resources are being limited through artificial water source removals and numbers are allowed to fluctuate naturally and are not controlled by culling. The focus of elephant conservation management has, therefore, changed from manipulating elephant numbers artificially to promoting ecological processes that may regulate numbers naturally (Owen-Smith et al., 2006; van Aarde \& Jackson, 2007).

The most prominent and contentious example of this changing focus occurred in the Kruger National Park, South Africa. From 1967 to 1994, Kruger managers culled 14,629 elephants to stabilise the population at a whimsically estimated 7000 individuals in an attempt to reduce the presumed negative effects of high densities on vegetation (van Aarde et al., 1999). During this time, approximately 300 artificial waterholes were established across the Park and, by 1976, Kruger was fully fenced and dispersal movement restricted. Thereafter, following public protest informed by science-based advocacy, culling ceased and elephant densities more than doubled from 1995 to 2012. This numerical response occurred despite managers removing more than half of artificial waterholes and dropping some fences between 1993 and 2002 . Although science-based objectives ultimately supported the sometimes seemingly haphazard changes in management (Owen-Smith et al., 2006), little has been done to directly evaluate how effective the changes were in achieving the expected outcomes.

One ecological objective was to restore resource limitations and, in doing so, potentially promote density-dependent processes that could regulate the elephant population. A process that is fundamental in promoting such a scenario is density-dependent habitat selection, suggestive of intraspecific competition for resources (Owen-Smith et al., 2006; 
Bonenfant et al., 2009). Theory advocates that at low population densities, animals distribute themselves across landscapes relative to high-quality habitats that provide optimal fitness returns (Fretwell \& Lucas, 1969). As population densities rise, intraspecific competition strengthens and per capita availability of high-quality habitats decreases (Fretwell \& Lucas, 1969). Consequently, some individuals in a population redistribute into lower quality habitats, the proximity of individuals to one another changes (McLoughlin et al., 2010) and habitat selection becomes more generalised (van Beest et al., 2014a; b). This may negatively influence individual fitness (McLoughlin et al., 2006; McLoughlin, Coulson \& Clutton-Brock, 2008) and ultimately contribute to population regulation through changes in survival and fecundity (see Morris, 1988; 2003).

Here, we evaluate how effective the changes in Kruger's elephant management approach were in promoting density-dependent habitat selection, a potential promoter of population regulation in elephants. We used annual dry season aerial surveys from 1998 to 2012 and resource selection functions (RSFs) (Manly et al., 2002; McLoughlin et al., 2010) to test the primary theoretical prediction that a two-fold increase in population density generalised fine-grain habitat selection by elephants (i.e. decreased selection of high quality habitat and increased selection of lower quality habitat) (Fretwell \& Lucas, 1969; van Beest et al., 2014a; b). As few studies have quantified fitness returns of specific habitats for elephants, we assumed that habitat selection at low densities would be indicative of high-quality habitats for elephants (Fretwell \& Lucas, 1969). We included two key factors that influence elephant habitat selection across southern Africa, namely woody vegetation cover and permanent water in the form of rivers (see Roever, van Aarde \& Leggett, 2012 and references therein). We assessed how changes in population density, as well as rainfall, influenced temporal variation in fine-grain habitat selection, recognising that density seldom operates in isolation (Mobæk et al., 2009; McLoughlin et al., 2010). We expected that as densities increased, elephants would make use 
of a greater area of Kruger (Young, Ferreira \& van Aarde, 2009) and selection would generalise (Fretwell \& Lucas, 1969; van Beest et al., 2014a; b). We further expected to find a response to temporal changes in rainfall, and specifically, that increased dry season rainfall would lead to selection farther from rivers (Redfern et al., 2003; Chamaillé-Jammes et al., 2007; Smit \& Ferreira, 2010). Finally, we anticipated that a density-dependent effect would be less evident in the southern compared to the northern and central districts of the Park due to the prevailing steep rainfall gradient (Gertenbach, 1980). We reasoned that the relatively high mean woody cover and low mean distance to rivers would potentially buffer selection against variation in density in the south (Mobæk et al., 2009).

\section{Material and methods}

\section{Study site}

The Kruger National Park covers $19485 \mathrm{~km}^{2}$ in the northeastern corner of South Africa. The northern, central and southern districts of the Park lie along a gradient of increasing rainfall from north (receiving an annual average of $450 \mathrm{~mm}$ ) to south $(750 \mathrm{~mm})$ (Gertenbach, 1980), and show differences in dominant vegetation types (Gertenbach, 1983; Kiker et al., 2014). Mean distance to rivers is lowest and spatially least variable in the south $(4939 \mathrm{~m} \pm 3568 \mathrm{~m})$, followed by the central $(5633 \mathrm{~m} \pm 4548 \mathrm{~m})$ and northern $(7395 \mathrm{~m} \pm 6152 \mathrm{~m})$ districts respectively (also see Fig. 1). Mean woody cover is highest and varies the least across space in the southern district $(40.11 \% \pm 6.34 \%)$; while the northern $(33.86 \% \pm 12.05 \%)$ and central $(33.19 \% \pm$ $11.53 \%$ ) districts are relatively similar (also see Fig. 1). 

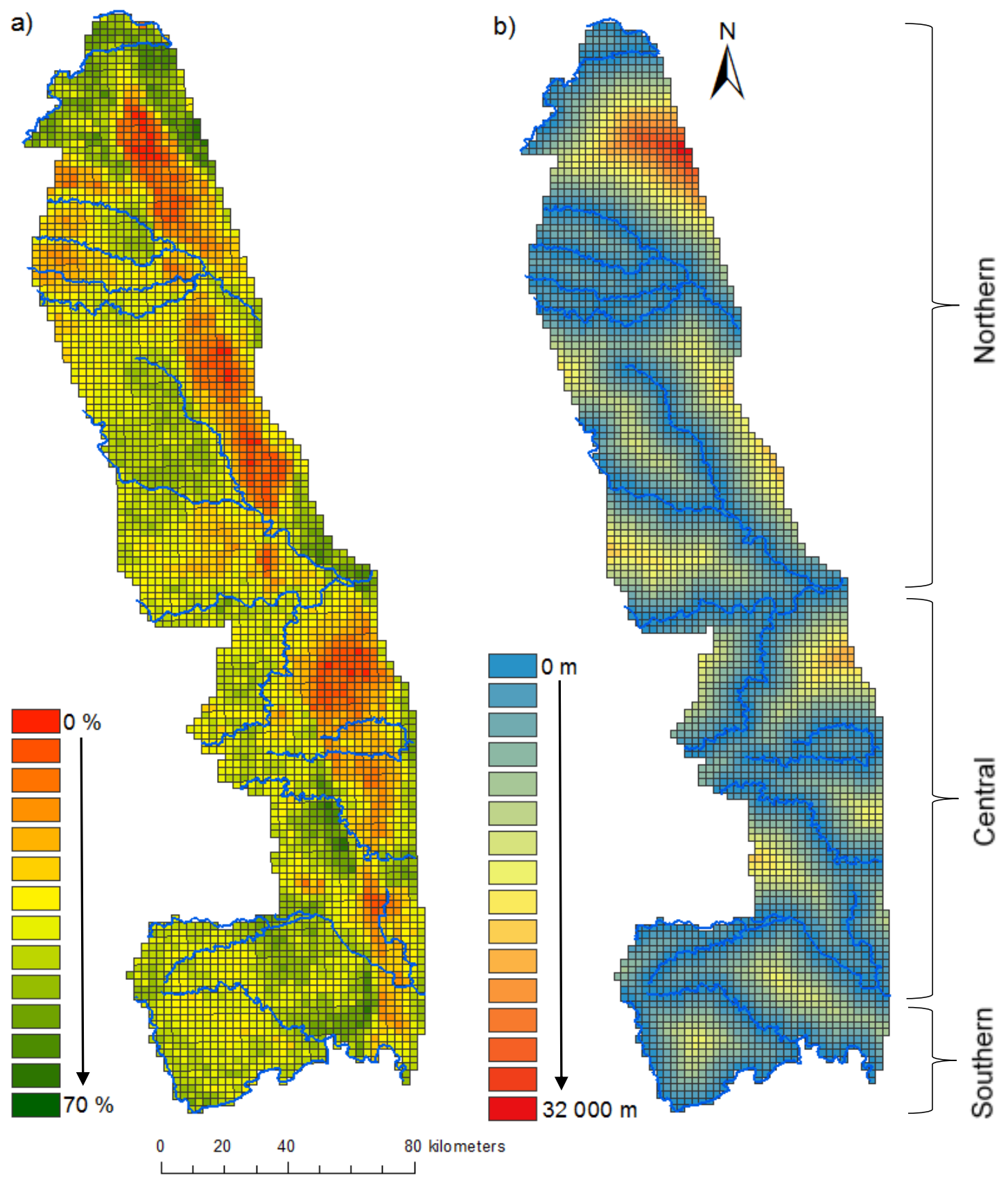

Figure 1. $5 \mathrm{~km}^{2}$ grid-cells of the Kruger National Park indicating a) mean percentage woody cover (see Bucini $e t$ al., 2010) and b) mean distance to rivers for each cell. We further show the districts of Kruger, with the northern district north of the Olifants river, the southern district south of the Sabie river, and the central district in-between.

\section{Elephant population surveys}

We used annual elephant surveys (1998-2012) to estimate elephant locations and population density in Kruger. These dry season aerial surveys, conducted using a helicopter, occurred 
during the same 18-day period each year, from the end of August to the middle of September (Whyte, 2001). Dry season surveys ensured optimal visibility. Kruger was divided into 18 survey blocks, with one block surveyed each day, starting in the north of the Park and concluding in the south (Whyte, 2001). Surveys were performed from 07:00 to 15:00 (GMT + 2) and the estimated mean area covered per day was $1055 \mathrm{~km}^{2}$ (Whyte, 2001). The helicopter flew at a mean altitude of $150 \mathrm{~m}$ above ground level and followed the extensive drainage network of the Kruger landscape, resulting in a 99\% coverage (Whyte, 2001). Four observers recorded elephant locations on handheld GPS units, counted all individuals and determined whether elephants were in a bull group or female dominated breeding herd. For simplicity, we differentiate between bull groups and female dominated breeding herds as "males" and "females" respectively. Helicopters have a considerable advantage over fixed-wing aircraft as they can easily reroute to a group of animals to record their location and hover over them until observers achieve a consensus on group size. Nevertheless, aerial surveys may still be susceptible to habitat sightability biases that can result in inaccurate estimates of habitat selection (Pollock \& Kendall, 1987). To validate the accuracy of our aerial survey data, we compared habitat-use estimated using this data to habitat-use estimated using telemetry data (van Beest et al., 2014a). We found habitat-use estimates using aerial survey data to be indicative of habitat-use during the dry season (Supporting Information Appendix S1). Because of the above reasons and due to the near-total coverage of Kruger, we consider elephant location and density estimates as precise and accurate (Whyte, 2001; Ferreira \& van Aarde, 2009).

\section{Spatial scale and habitat covariates}

We divided Kruger into $5 \mathrm{~km}^{2}$ grid-cells (see Fig. 1). We chose this scale as it represents estimates of the mean area used daily by elephants in the Park (data from the CERU telemetry database). Considering that the temporal scale of the survey only allowed us to estimate a 
habitat selection "snap shot" based on once-off location data, this spatial scale seemed the most appropriate for a highly mobile herbivore (Young et al., 2009). Grid-cells of $5 \mathrm{~km}^{2}$ also allowed us to capture heterogeneity in the landscape which would have likely been overlooked if we used larger grid-cells (e.g. $100-400 \mathrm{~km}^{2}$, representing variability in dry season home range sizes) (Boyce, 2006; Young et al., 2009).

Elephants are water-dependent. Therefore, we used distance to large perennial, and seasonal rivers as a covariate in estimating habitat selection (see Fig. 1) (Smit \& Ferreira, 2010). We additionally used estimations of woody vegetation cover (Bucini et al., 2010). The percentage woody cover layer incorporated elements of vegetation productivity and structure (Bucini et al., 2010), making it a good index of both forage and shade availability (see Fig. 1). We could not consider year-to-year depletion or accumulation of woody vegetation explicitly within our analyses. However, we consider our use of a static woody cover layer as appropriate within the scope of our study (Supporting Information Appendix S2).

Various studies have reported that distance to rivers and woody cover have strong influences on elephant habitat selection across Africa (Harris et al., 2008; Loarie, van Aarde \& Pimm, 2009a; Lindsay, 2011; Roever et al., 2012; Roever, van Aarde \& Chase, 2013). Furthermore, with prospective links between habitat selection and density-dependent population regulation in mind, we focused on covariates that appear to drive variation in a number of components of elephant demography (i.e. calf survival, fecundity and dispersal) (Wittemyer, Rasmussen \& Douglas-Hamilton, 2007; Chamaillé-Jammes et al., 2008; Young \& van Aarde, 2010). We were unable to use distance to waterholes as a habitat covariate (see below).

\section{Estimating the influence of density and rainfall on habitat selection}

Resource selection functions (RSFs) are powerful tools for studying ecological processes related to habitat selection. They have been used to infer fitness-habitat relationships 
(McLoughlin et al., 2006) and, more recently, to assess the effects of density on selection patterns (van Beest et al., 2014a; b). Given the strong theoretical and empirical linkages between habitat selection and fitness (see Introduction), as well as the suitability and acceptance in the literature of using RSFs to account for potential density-dependent effects on selection (McLoughlin et al., 2010; van Beest et al., 2014a; b), we decided to use an RSF framework in this study.

We used RSFs to separately estimate female and male dry season habitat selection for the entire study period (1998 - 2012). We calculated RSFs for the whole Park, and separately for the northern, central and southern districts (see Study Site). Our analyses matched most closely with a population-level use-availability sampling design (Thomas \& Taylor, 2006). We specified a grid-cell as used (1) when $\geq 1$ elephant was observed in that cell during the survey. For each year, we randomly drew available cells (0) from all cells throughout Kruger or the appropriate district. The ratio of used cells: available cells was 1:1.

Prior to analysis, we standardised all Kruger-wide and district-specific continuous variables by centring and dividing by two standard deviations. This facilitated model convergence and comparison. Within a mixed-effect logistic regression model (Gillies et al., 2006; McLoughlin et al., 2010; van Beest et al., 2014a; b), we related used (1) and available (0) cells (dependent variable) to percentage woody cover, distance to rivers, density and mean dry season rainfall, as well the interactions between the habitat covariates and population density and mean dry season rainfall (independent variables). We estimated mean dry season rainfall (June to September inclusive) using monthly rainfall estimates from 30 rainfall stations across Kruger $($ northern $=14$; central $=8$; southern $=8$ ). We accounted for unbalanced data across years and between districts by including district nested within year as a random intercept for the Kruger-wide RSF. For the district-specific RSFs, we only included year as a random intercept. We evaluated the predictive success of each model using k-fold cross-validation (k 
$=5$ ) and the Spearman rank correlation coefficient (Boyce et al., 2002). All RSFs were calculated using R (R Development Core Team, 2013). To ensure that potential changes in habitat selection were related to temporal variation in density and/or dry season rainfall, and not due to year-to-year changes in the distribution of habitat covariates in randomly chosen available grid-cells, we compared yearly available distributions to the overall distribution of each habitat covariate. The distributions of habitat covariates in randomly chosen available grid-cells were similar throughout our study period (Supporting Information Appendix S3).

From 1998 to 2012, management in Kruger actively reduced the number of boreholefed waterholes by approximately 65\% (see Fig. S4). The exact timing and locality of closures were, however, unavailable, therefore distance to waterholes could not be included as a covariate in all of our RSFs. We determined that female - but not male - habitat selection estimates independent of waterholes were appropriate (Supporting Information Appendix S4) and, therefore, excluded male elephant habitat selection estimates from our paper.

\section{Results}

\section{Density and grid-cell occupancy}

Elephant density in Kruger increased from 0.47 elephants $/ \mathrm{km}^{2}$ in 1998 to a high of 0.85 in 2012 (Fig. S5). Over the 15-year period, increases in density were greatest in the southern district, followed by the northern and central (Fig. S5). Female occupancy of grid-cells increased with density at the Kruger-wide scale as well as in each district (Fig. 2). Occupancy increased linearly with density for the whole Park and the central and southern districts, whereas a quadratic relationship indicated a slight leveling-off of occupancy at high densities in the north (Fig. 2). At high densities, occupancy was highest in the southern district, followed by the central and northern (Fig. 2). 


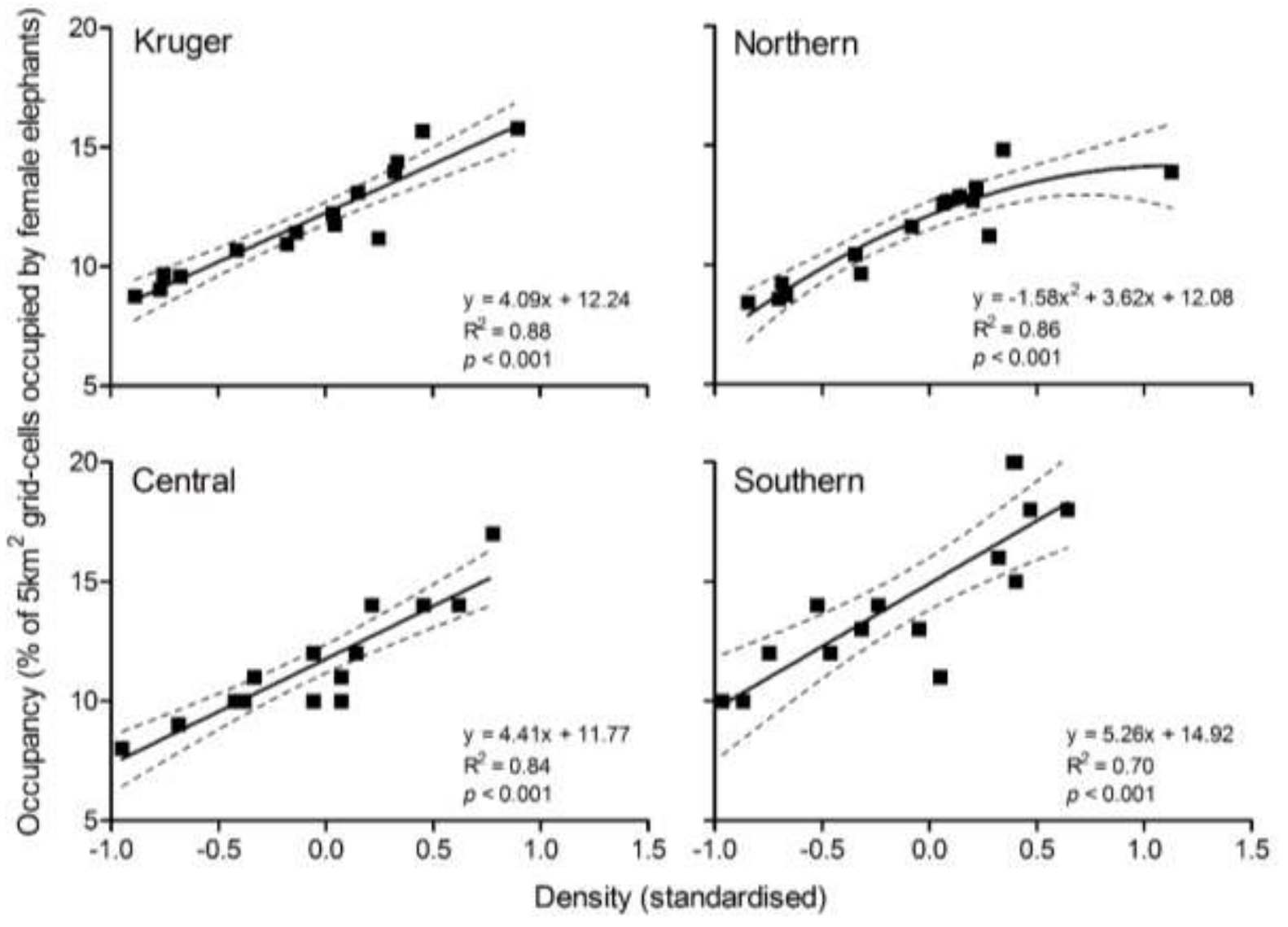

Figure 2. Occupancy as a function of density for the whole of Kruger, and the northern, central and southern districts. We used linear regression to relate the percentage of $5 \mathrm{~km}^{2}$ grid-cells occupied by female elephants to density. Additionally, we assessed whether a second order polynomial performed better than the linear fit using the Akaike information criterion (AIC) (Burnham \& Anderson, 2002), where $\Delta \mathrm{AIC}_{\mathrm{c}}<-2$. Dashed lines are $95 \%$ confidence intervals. Density was standardised by centring and dividing by two standard deviations.

\section{Habitat selection estimates}

In general, female elephants across all districts selected for areas with a relatively high percentage of woody cover and that were relatively close to rivers (Table S2). The interaction between woody cover and density revealed, however, that increased density influenced woody cover selection at the Kruger-wide and district-specific scales (Table S2). For the whole of Kruger and the northern district, increasing density led to a significant decrease in selection for high woody cover (Kruger: $\beta_{\text {woody cover } \times \text { density }}=-0.27 \pm 0.08, p<0.001$; northern district: $\beta_{\text {woody }}$ cover $\times$ density $=-0.31 \pm 0.11, p=0.003$ ) (Fig. 3) (Table S2). In the central and southern districts, 

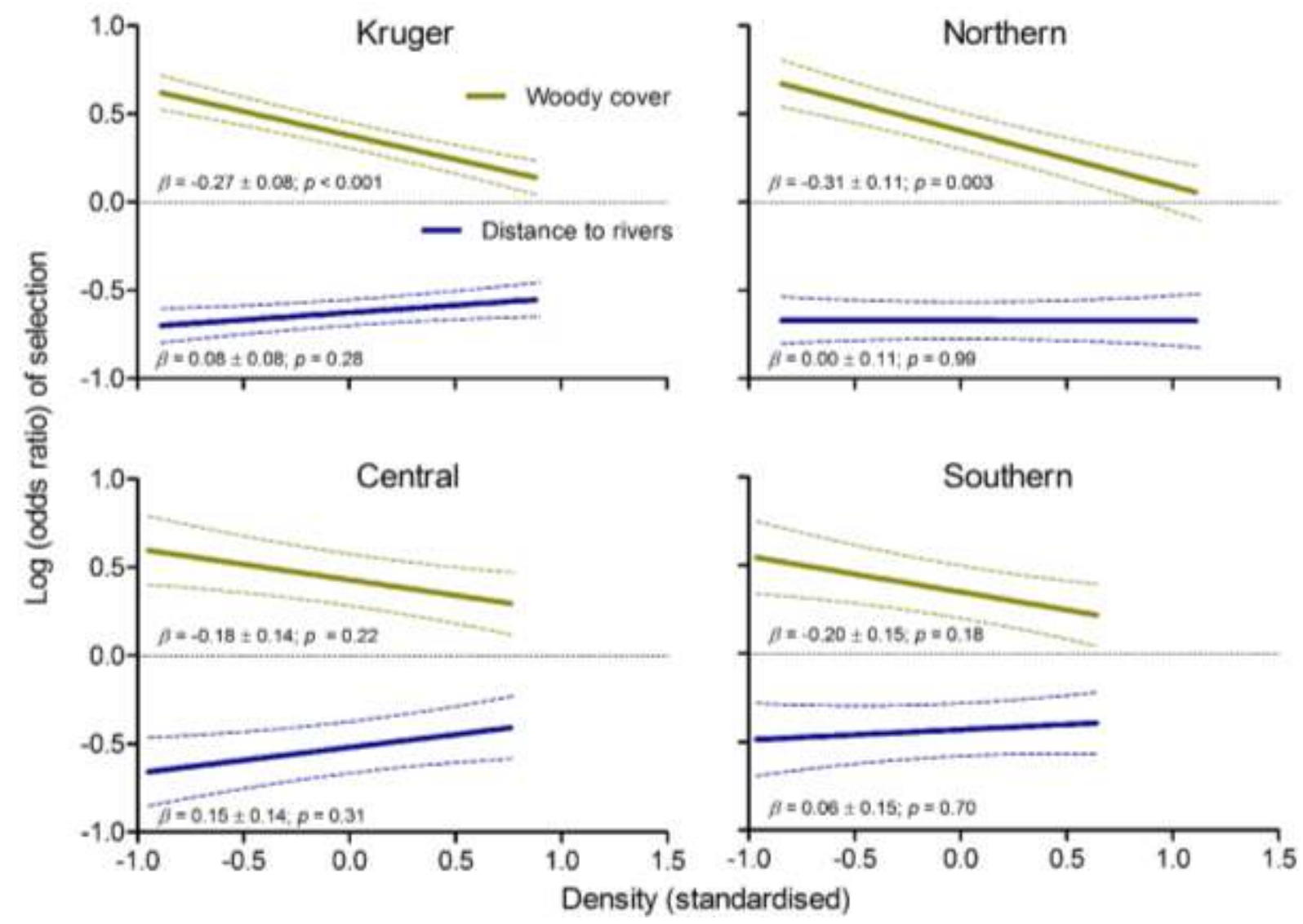

Figure 3. Resource selection function estimates (log odds ratio $\pm 95 \%$ confidence intervals) for female elephant selection of woody cover and distance to rivers, as a function of density, for the whole of the Kruger National Park and its northern, central and southern districts (1998 - 2012). Woody cover, distance to rivers and density are standardised by centring and dividing by two standard deviations.

increasing density had no effect on selection for woody cover (central district: $\beta_{\text {woody cover } \times \text { density }}$ $=-0.18 \pm 0.14, p=0.22 ;$ southern district: $\beta$ woody cover $\times$ density $=-0.20 \pm 0.15, p=0.18$ ) (Fig. 3)

(Table S2). Conversely, the interaction between distance to rivers and density suggested that an increase in density had very little effect on female selection for rivers in any district (Fig. 3) (Table S2). Instead, for the whole of Kruger and the central and southern districts, increased dry season rainfall significantly increased selection for areas relatively far away from rivers (Kruger: $\beta$ distance to rivers $\times$ dry rain $=0.14 \pm 0.08, p=0.05$; central district: $\beta$ distance to rivers $\times$ dry rain $=$ $0.43 \pm 0.18, p=0.02$; southern district: $\beta$ distance to rivers $\times$ dry rain $=0.70 \pm 0.14, p<0.001)$ (Fig. 4 ) (Table S2). Selection for rivers was unaffected by changes in dry season rainfall in the northern 
district (Fig. 4) (Table S2), potentially due to the timing of surveys relative to rainfall events. Last, variation in dry season rainfall did not appear to affect female elephant selection of woody cover in any district (Fig. 4) (Table S2). Spearman rank correlation across five cross-validation sets showed that all female RSFs had very good predictive performance (Kruger: $r_{s}=0.993, p$ $<0.001$; northern district: $r_{s}=0.968, p<0.001$; central district: $r_{s}=0.982, p<0.001$; southern district: $\left.r_{s}=0.933, p<0.001\right)$. For a discussion on the exclusion of the influence of wet season rainfall on the dry season habitat selection of elephants in Kruger, see Supporting Information (Appendix S7).
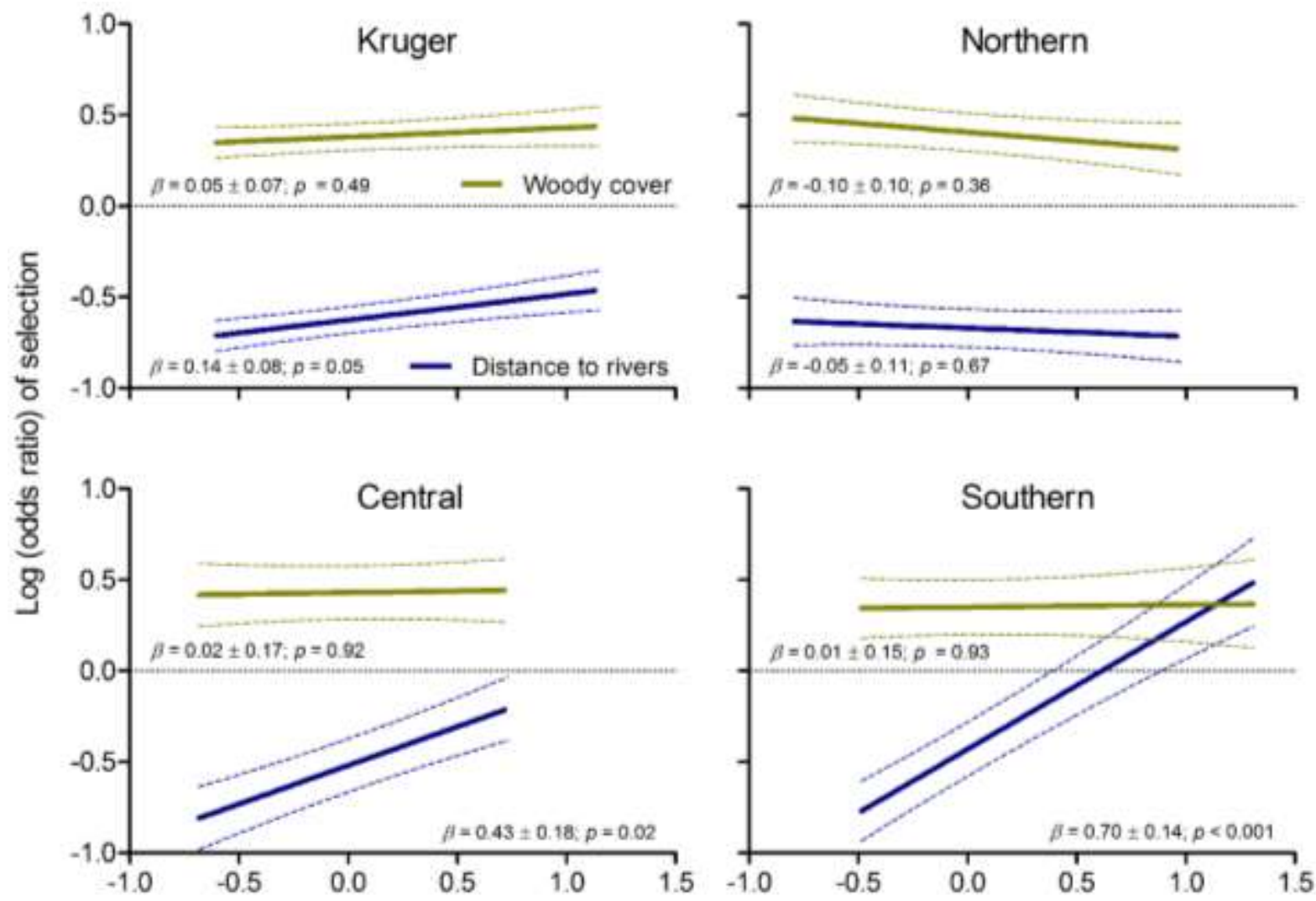

Mean dry season rainfall (standardised)

Figure 4. Resource selection function estimates (log odds ratio $\pm 95 \%$ confidence intervals) for female elephant selection of woody cover and distance to rivers, as a function of mean dry season rainfall, for the whole of the Kruger National Park and its northern, central and southern districts (1998 - 2012). Woody cover, distance to rivers and mean dry season rainfall are standardised by centring and dividing by two standard deviations. 


\section{Discussion}

Our "snapshot" estimates of elephant habitat selection in the Kruger National Park confirmed earlier findings; female elephants select areas relatively close to water and with high woody cover (Harris et al., 2008; Loarie et al., 2009a; Roever et al., 2012; Roever et al., 2013). However, in this study, we show that habitat selection, and specifically selection for woody cover, was clearly density-dependent in parts of Kruger. This suggests that changes in conservation management approaches for elephants in Kruger were effective in achieving at least some of the ecological expectations of management.

As per our predictions, and following on from the work of Young et al. (2009), female elephant occupancy increased with density in Kruger, although not uniformly across the three districts. This provided an initial indication of density-dependent habitat selection (Matthysen, 2005), as some individuals had to redistribute into previously unoccupied areas as density increased. A more compelling finding suggesting density-dependent habitat selection was that an increase in Kruger-wide and district-specific densities also led to a generalisation in woody cover selection and land use. At low densities, female elephants across all districts were able to select for areas with a relatively high percentage of woody cover. As densities increased, some female elephants redistributed into areas of lower woody cover, and woody cover selection became more diffuse through the landscape. As with occupancy, this did not occur equally across Kruger. The effect of density was weak and insignificant in the central and southern districts. Elephants in these districts increased occupancy in response to increasing density as seen in the north. However, they may have been able to redistribute into previously unoccupied areas of high woody cover in these relatively woody districts. As such, densitydependent woody cover selection was less evident in the central and southern districts, compared to the northern district, of Kruger. This spatial difference may operate in the same way that temporal variation in resource availability can influence the strength of intraspecific 
competition (suggested in Mobæk et al., 2009). Moreover, we could not account for potential district-specific differences in diet (e.g. greater grass intake in the northern district than central and southern districts during the dry season) (Codron et al., 2011), species-specific feeding in the heterogeneous central and southern districts (Loarie et al., 2009a) or possible changes in woody cover (Buitenwerf et al., 2012; but see Supporting Information Appendix S2). Nonetheless, the generalisation in woody cover selection suggests a novel identification of finegrain density-dependent habitat selection for elephants that is in line with ecological theory and the objectives of Kruger management.

Woody vegetation constitutes an important resource for female elephants. Elephants switch from a grass-dominated diet in the wet season to a browse-dominated diet in the dry (Codron et al., 2011; Shannon, Mackey \& Slotow, 2013). During this critical period, woody vegetation may provide nutrients to sustain pregnancy and to recover from parturition events (Wittemyer et al., 2007) and can influence the survival of weaned calves by determining the distance of foraging trips (Young \& van Aarde, 2010). Conceptually, a density-dependent generalisation in woody cover selection could then have demographic consequences for elephants. Subsequently, this could limit population growth, the intended outcome of the changes in conservation management in Kruger. Future research should, therefore, seek to establish empirically the linkages between density-dependent habitat selection, demographic variation (see McLoughlin et al., 2006; McLoughlin et al., 2008), and ultimately, population regulation. To establish such linkages, it would be preferable to examine how both male and female elephants respond to changes in density, something that we could not achieve in this study.

Unlike selection for woody cover, the selection of rivers was surprisingly unrelated to changes in density (Smit \& Ferreira, 2010). Instead, for Kruger and the central and southern districts, the amount of rainfall received during the dry season explained the strength of 
selection for areas close to rivers. We found that an increase in mean dry season rainfall led to female elephants increasingly selecting for areas farther from rivers. In Kruger, intermittent dry season rainstorms can result in water sources forming independent of large rivers, possibly in smaller rivers and drainage lines (Redfern et al., 2003; Smit \& Ferreira, 2010). Although these temporary water points may only be present for a short period, they can still influence the dry season distribution of large, mobile herbivores such as elephants (Western, 1975; Trash \& Derry, 1999; Redfern et al., 2003; Smit \& Ferreira, 2010). High dry season rainfall may extend key-resource areas farther from permanent surface-water, temporarily lifting normal dry season foraging restrictions (Illius \& O’Connor, 2000; Chamaillé-Jammes et al., 2008) and allowing female elephants to imitate their wet season selection patterns (Roever et al., 2012). Although unrelated directly to changes in density, variation in dry season river selection may modify the strength of density-dependence by varying local forage availability and aggregation around key-resource areas (Chamaillé-Jammes et al., 2008). Future studies should, therefore, consider the effects of density and rainfall - and interactions between them - on elephant habitat selection at a scale finer than the population-level assessment used here (e.g. McLoughlin et al., 2006).

Initial conservation management decisions to fence Kruger, supplement water in relatively dry areas and stabilize the elephant population through culling affected elephant movement patterns and decoupled demographic variation from ecological limitations (Walker et al., 1987; van Aarde et al., 1999; Loarie, van Aarde \& Pimm, 2009b; Shrader et al., 2010). For example, the Kruger elephant population continued to grow despite a severe drought from 1981 to 1983 , while the mortality rate of other large herbivore populations increased markedly (Walker et al., 1987). Density-dependent processes were likely absent during that period as managers capped the elephant population well below any realistic ecological carrying capacity (Walker et al., 1987; Owen-Smith et al., 2006). Furthermore, supplemented water likely 
alleviated natural foraging restrictions, allowing these highly mobile herbivores to access remote foraging areas (Loarie et al., 2009b) and avoid local crowding that may occur during dry phases (Chamaillé-Jammes et al., 2008). The manipulative focus of past management approaches then resulted in a number of ecological irregularities and carried additional financial burdens and social controversies (van Aarde \& Jackson, 2007).

Changes in conservation management approaches during the mid-1990s made theoretical sense. In particular, ecological theory suggested that density-dependent processes would ultimately regulate the population if elephant numbers were allowed to fluctuate spatiotemporally without intensive management intervention (Owen-Smith et al., 2006). Our identification of density-dependent habitat selection - suggestive of competition for resources - suggests that the changes in conservation management approaches for elephants in Kruger were effective in promoting a potential driver of population regulation. However, given that the ecological carrying capacity of Kruger's elephant population is possibly more than double the highest density observed during our study period (see Robson et al., 2017), it is likely that density-dependent habitat selection will have delayed demographic consequences that stabilise the population in the future. Such delayed demographic effects are expected for populations of large, long-lived herbivores like elephants (Bonenfant et al., 2009; Lee et al., 2013).

We acknowledge that this is an initial examination of the far-reaching effects of changes in management as we could only directly assess how female selection for two habitat covariates responded to changes in one component of management (i.e. the moratorium on culling). Indeed, given the emphasis that Kruger managers have placed on the revised water supplementation scheme and the work of, for example, Chamaillé-Jammes, Valeix \& Fritz (2007), Hilbers et al. (2015) and Purdon \& van Aarde (2017), our study would have benefitted from an assessment of the influence of reduced water supplementation on habitat selection. Additionally, elephants and elephant management invariably affect other species and the 
dynamics of savanna ecosystems (Owen-Smith et al., 2006). An evaluation of the influence of changes in elephant habitat selection on, for example, interspecific competition (Valeix, Chamaillé-Jammes \& Fritz, 2007; van Beest et al., 2014a), savanna vegetation (Guldemond \& van Aarde, 2008) and processes (Guldemond, Purdon \& van Aarde, 2017), and changes in the magnitude of habitat-specific utilisation pressures (Smit \& Ferreira, 2010) would have provided a more holistic view of the conservation management scenario in Kruger. We are, however, confident that the absence of these and the water supplementation assessment does not detract from our main finding that female elephants in Kruger responded as expected to changes in management approaches (see Smit, Grant \& Whyte, 2007). Therefore, our study provides evidence that a no- or limited-intervention approach focusing on ecological processes remains a viable conservation management option for elephants in Kruger and elsewhere.

Nonetheless, our results should be considered in conjunction with other ecological (e.g. conserving rare plant species), social (e.g. avoiding human-wildlife conflict) and/or economic (e.g. attracting tourism) objectives of an adaptive management strategy (see van Wilgen \& Biggs, 2011). For example, while increasing elephant densities could result in the restoration of natural self-regulation for Kruger's elephants, elevated densities could also, conceivably, lead to an undesirable increase in human-wildlife conflict in communities surrounding the park. Additionally, higher elephant densities could result in changes to vegetation structure contrary to management goals and public perceptions of aesthetic appeal that developed during periods of artificially low elephant densities. In such instances, managers should evaluate the ecological, social and economic objectives of their management strategy to develop appropriate remedial actions. Our work supports the need to use informative scientific evidence rather than conjecture when doing so (Pullin et al., 2004; Owen-Smith et al., 2006). 


\section{Acknowledgements}

We thank SANParks Conservation Services Division, the International Fund for Animal Welfare and the University of Pretoria for their support. We are grateful to Judith Botha (SANParks Scientific Services) for supplying rainfall and elephant census data and to Sam Ferreira who facilitated the sanctioning of our research activities.

\section{Data Accessibility}

Elephant census and rainfall data are archived in the South African National Park Data Repository (http://dataknp.sanparks.org/sanparks/). Data are access protected and requests for access should be directed to Judith Botha, SANParks Scientific Services (judith.botha@sanparks.org).

\section{References}

Bonenfant, C., Gaillard, J-P., Coulson, T., Festa-Bianchet, M, Loison, A., Garel, M., Loe, L.E., Blanchard, P., Pettorelli, N., Owen-Smith, N., du Toit, J. \& Duncan, P. (2009). Empirical evidence of density-dependence in populations of large herbivores. $A d v$. Ecol. Res. 41, 313-357.

Boyce, M.S. (2006). Scale for resource selection functions. Divers. Distrib. 12, 269-276.

Boyce, M.S., Vernier, P.R., Nielsen, S.E. \& Schimiegelow, F.K.A. (2002). Evaluating resource selection functions. Ecol. Modell. 157, 281-300.

Bucini, G., Hanan, N.P., Boone, R.B., Smit, I.P.J., Saatchi, S.S., Lefsky, M.A. \& Asner, G.P. (2010). Woody fractional cover in Kruger National Park, South Africa: remote sensingbased maps and ecological insights. In Ecosystem function in savannas: Measurement and modelling at landscape to global scales: 219-237. Hill, M.J. \& Hanan, N.P. (Eds.). London: CRC Press. 
Buitenwerf, R., Bond, W.J., Stevens, N. \& Trollope, W.S.W. (2012). Increased tree densities in South African savannas: >50 years of data suggests $\mathrm{CO}_{2}$ as a driver. Global Change Biol. 18, 675-684.

Burnham, K.P. \& Anderson, D.R. (2002). Model selection and Multimodel Inference: A Practical Information-Theoretic Approach, $2^{\text {nd }}$ edn. New York: Springer-Verlag.

Chamaillé-Jammes, S., Fritz, H., Valeix, M., Murindagomo, F. \& Clobert, J. (2008). Resource variability, aggregation, and direct density dependence in an open context. The local regulation of an elephant population. J. Anim. Ecol. 77, 135-144.

Chamaillé-Jammes, S., Valeix, M. \& Fritz, H. (2007). Managing heterogeneity in elephant distribution: interactions between elephant population density and surface-water availability. J. Appl. Ecol. 44, 625-633.

Codron, J., Codron, D., Lee-Thorp, J.A., Sponheimer, M., Kirkman, K., Duffy, K.J. \& Sealy, J. (2011). Landscape-scale feeding patterns of African elephant inferred from carbon isotope analysis of feces. Oecologia 165, 89-99.

Croze, H. \& Lindsay, W.K. (2011). Amboseli ecosystem context: past and present. In The Amboseli elephants: a long-term perspective on a long-lived mammal: 11-28. Moss, C.J., Croze, H. \& Lee, P.C. (Eds.). Chicago: The University of Chicago Press.

Davidson, T. (1967). Wankie. The Story of a Great Game Reserve. Cape Town: Books of Africa.

Ferreira, S.M. \& van Aarde, R.J. (2009). Aerial survey intensity as a determinant of estimates of African elephant population sizes and trends. South African Journal of Zoology 39, $181-191$.

Fretwell, S.D. \& Lucas, H.L.Jr. (1969). On territorial behaviour and other factors influencing habitat distribution in birds. Acta Biotheor. 14, 16-36.

Gertenbach, W.P.D. (1980). Rainfall patterns in the Kruger National Park. Koedoe 23, 35-43. 
Gertenbach, W.P.D. (1983). Landscapes of the Kruger National Park. Koedoe 26, 9-121.

Gillies, C.S., Hebblewhite, M., Nielsen, S.E., Krawchuk, M.A., Aldridge, C.L., Frair, J.L., Saher, D.J., Stevens, C.E. \& Jerde, C.L. (2006). Application of random effects to the study of resource selection by animals. J. Anim. Ecol. 75, 887-898.

Guldemond, R. \& van Aarde, R. (2008). A meta-analysis of the impact of African elephants on savanna vegetation. J. Wildl. Manage. 72, 892-899.

Guldemond, R., Purdon, A. \& van Aarde, R.J. (2017) A systematic review of elephant impact across Africa. PLoS ONE 12, e0178935.

Hanks, J., Densham, W.D., Smuts, G.L., Jooste, J.F., Joubert, S.C.J., le Roux, P. \& Milstein, P.le S. (1981). Management of locally abundant large mammals: the South African experience. In Problems in Management of Locally Abundant Wild Mammals: 21-56. Jewell, P.A. \& Holts, S. (Eds.). New York: Academic Press.

Harris, G.M., Russell, G.J., van Aarde, R.J. \& Pimm, S.L. (2008). Rules of habitat use by elephants (Loxodonta africana) in southern Africa: insights for regional management. Oryx 42, 66-75.

Hilbers, J.P., van Langevelde, F., Prins, H.H.T., Grant, C.C., Peel, M., Coughenour, M.B., de Knegt, H.J., Slotow, R., Smit, I.P.J, Kiker, G.A. \& de Boer, W.F. (2015). Modeling elephant-mediated cascading effects of water point closure. Ecol. Appl. 25, 402-415.

Illius, A.W. \& O’Connor, T.G. (2000). Resource heterogeneity and ungulate population dynamics. Oikos 89, 283-294.

Kerley, G.I.H. \& Shrader, M. (2007). Elephant contraception: silver bullet or a potentially bitter pill? S. Afr. J. Sci. 103, 181-182.

Kiker, G.A., Scholtz, R., Smit, I.P.J. \& Venter, F.J. (2014). Exploring an extensive dataset to establish woody vegetation cover and composition in Kruger National Park for the late 1980s. Koedoe. (Online: DOI:10.4102/koedoe.v56i1.1200). 
Lee, P.C., Bussière, L.F., Webber, C.E., Poole, J.H. \& Moss, C.J. (2013). Enduring consequences of early experiences: 40 year effects on survival and success among African elephants (Loxodonta africana). Biol. Lett. 9, 20130011, http://dx.doi.org/10.1098/rsbl.2013.0011.

Lindsay, W.K. (2011). Habitat use, diet choice, and nutritional status in female and male Amboseli elephants. In The Amboseli elephants: a long-term perspective on a longlived mammal: 51-73. Moss, C.J., Croze, H. \& Lee, P.C. (Eds.). Chicago: The University of Chicago Press.

Loarie, S.R., van Aarde, R.J. \& Pimm, S.L. (2009a). Elephant seasonal vegetation preferences across dry and wet savannas. Biol. Conserv. 142, 3099-3107.

Loarie, S.R., van Aarde, R.J. \& Pimm, S.L. (2009b). Fences and artificial water affect African savannah elephant movement patterns. Biol. Conserv. 142, 3086-3098.

Manly, B.F.J., McDonald, L.L., Thomas, D.L., McDonald, T.L. \& Erickson, W.P. (2002). Resource selection by Animals: Statistical Analysis and Design for Field Studies. Netherlands: Kluwer Academic Publishers, Dordrecht.

Matthysen, E. (2005). Density-dependent dispersal in birds and mammals. Ecography 28, 403416.

McLoughlin, P.D., Boyce, M.S., Coulson, T. \& Clutton-Brock, T. (2006). Lifetime reproductive success and density-dependent, multi-variable resource selection. Proc. $R$. Soc. Lond. B. Biol. Sci. 273, 1449-1454.

McLoughlin, P.D., Coulson, T. \& Clutton-Brock, T. (2008). Cross-generational effects of habitat and density on life history in red deer. Ecology 89, 3317-3326.

McLoughlin, P.D., Morris, D.W., Fortin, D., Vander Wal, E. \& Contasti, A.L. (2010). Considering ecological dynamics in resource selection functions. J. Anim. Ecol. 79, 412. 
Mobæk, R., Mysterud, A., Loe, L.E., Holand, Ø. \& Austrheim, G. (2009). Density dependent and temporal variability in habitat selection by a large herbivore; an experimental approach. Oikos 118, 209-218.

Morris, D.W. (1988). Habitat-dependent population regulation and community structure. Evol. Ecol. 2, 253-269.

Morris, D.W. (2003). Toward an ecological synthesis: a case for habitat selection. Oecologia 136, 1-13.

O'Connor, T.G., Goodman, P.S. \& Clegg, B. (2007). A functional hypothesis of the threat of local extirpation of woody plant species by elephant in Africa. Biol. Conserv. 136, 329345.

Owen-Smith, N. (1996). Ecological guidelines for waterpoints in extensive protected areas. $S$. Afr. J. Wildl. Res. 26, 107-112.

Owen-Smith, N., Kerley, G.I.H., Page, R., Slotow, R. \& van Aarde, R.J. (2006). A scientific perspective on the management of elephants in the Kruger National Park and elsewhere. S. Afr. J. Sci. 102, 389-394.

Pienaar, U.de V. \& van Niekerk, J.W. (1963). Elephant control in national parks. Oryx 7, 3538.

Pienaar, U.de V. (1983). Management by interventions: the pragmatic/economic option. In Management of Large Mammals in African Conservation Areas: 23-36. Owen-Smith, N. (Ed.). Pretoria: HAUM.

Pollock, K.H. \& Kendall, W.L. (1987). Visibility bias in aerial surveys: a review of estimation procedures. J. Wildl. Manage. 51, 502-510.

Pullin, A.S. \& Knight, T.M. (2001). Effectiveness in conservation practice: pointers from medicine and public health. Conserv. Biol. 15, 50-54. 
Pullin, A.S., Knight, T.M., Stone, D.A. \& Charman, K. (2004). Do conservation managers use scientific evidence to support their decision-making? Biol. Conserv. 119, 245-252.

Purdon, A. \& van Aarde, R.J. (2017). Water provisioning in Kruger National Park alters elephant spatial utilisation patterns. J. Arid Environ. 141, 45-51.

R Core Team (2013). R: a language and environment for statistical computing. Vienna, Austria: $\mathrm{R}$ foundation for Statistical Computing.

Redfern, J.V., Grant, R., Biggs, H. \& Getz, W.M. (2003). Surface-water constraints on herbivore foraging in the Kruger National Park, South Africa. Ecology 84, 2092-2107.

Robson, A.S., Trimble, M.J., Purdon, A., Young-Overton, K.D., Pimm, S.L. \& van Aarde, R.J. (2017). Savanna elephant numbers are only a quarter of their expected values. PLoS ONE 12, e0175942, https://doi.org/10.1371/journal.pone.0175942.

Roever, C.L., van Aarde, R.J. \& Chase, M.J. (2013). Incorporating mortality into habitat selection to identify secure and risky habitats for savannah elephants. Biol. Conserv. 164, 98-106.

Roever, C.L., van Aarde, R.J. \& Leggett, K. (2012). Functional responses in the habitat selection of a generalist mega-herbivore, the African savannah elephant. Ecography 35, 972-982.

Shannon, G., Mackey, R.L. \& Slotow, R. (2013). Diet selection and seasonal dietary switch of a large sexually dimorphic herbivore. Acta Oecol. 46, 48-55.

Shrader, A.M., Pimm, S.L. \& van Aarde, R.J. (2010). Elephant survival, rainfall and the confounding effects of water provision and fences. Biodivers. Conserv. 19, 2235-2245.

Skarpe, C., Aarrestad, P.A., Andreassen, H.P., Dhillion, S.S., Dimakatso, T., Du Toit, J.T., Halley, D.J., Hytteborn, H., Makhabu, S., Mari, M., Marokane, W., Masunga, G., Modise, D., Moe, S.R., Mojaphoko, R., Mosugelo, D., Motsumi, S., Neo-Mahupeleng, G., Ramotadima, M., Rutina, L., Sechele, L., Sejoe, T.B., Stokke, S., Swenson, J.E., 
Taolo, C., Vandewalle, M. \& Wegge, P. (2004) The return of the giants: ecological effects of an increasing elephant population. Ambio, 33, 276-282.

Smit, I.P.J. \& Ferreira, S.M. (2010). Management intervention affects river-bound spatial dynamics of elephants. Biol. Conserv. 143, 2172-2181.

Smit, I.P.J., Grant, C.C. \& Whyte, I.J. (2007). Landscape-scale sexual segregation in the dry season distribution and resource utilization of elephants in Kruger National Park, South Africa. Divers. Distrib. 13, 225-236.

Thomas, D.L. \& Taylor, E.J. (2006). Study designs and tests for comparing resource use and availability II. J. Wildl.Manage. 70, 324-336.

Trash, I. \& Derry, J.F. (1999). The nature and modelling of piospheres: a review. Koedoe 42, 73-94.

Trimble, M.J. \& van Aarde, R.J. (2010). Species inequality in scientific studies. Conserv. Biol. 24, 886-890.

Valeix, M., Chamaillé-Jammes, S. \& Fritz, H. (2007). Interference competition and temporal niche shifts: elephants and herbivore communities at waterholes. Oecologia 153, 739_ 748.

van Aarde, R., Whyte, I. \& Pimm, S. (1999). Culling and the dynamics of the Kruger National Park African elephant population. Anim. Conserv. 2, 287-294.

van Aarde, R.J. \& Jackson, T.P. (2007). Megaparks for metapopulations: addressing the causes of locally high elephant numbers in southern Africa. Biol. Conserv. 134, 289-297.

van Aarde, R.J., Jackson, T.P. \& Ferreira, S.M. (2006). Conservation science and elephant management in southern Africa. S. Afr. J. Sci. 102, 385-388.

van Beest, F. M., McLoughlin, P.D., Vander Wal, E. \& Brook, R.K. (2014a). Densitydependent habitat selection and partitioning between two sympatric ungulates. Oecologia. (Online: DOI 10.1007/s00442-014-2978-7). 
van Beest, F.M., Uzal, A., Vander Wal, E., Laforge, M.P., Contasti, A.L., Colville, D. \& McLoughlin, P.D. (2014b). Increasing density leads to generalisation in both coarsegrained habitat selection and fine-grained resource selection in a large mammal. $J$. Anim. Ecol. 83, 147-156.

van Wilgen, B.W. \& Biggs, H.C. (2011). A critical assessment of adaptive ecosystem management in a large protected area in South Africa. Biol. Conserv. 144, 1179-1187.

Walker, B.H., Emslie, R.H., Owen-Smith, N. \& Scholes, R.J. (1987). To cull or not to cull: lessons from a southern African drought. J. Appl. Ecol. 24, 381-401.

Western, D. (1975). Water availability and its influence on the structure and dynamics of a savannah large mammal community. East Afr. Wildl. J. 13, 265-286.

Whyte, I. J. (2001). Conservation management of the Kruger National Park elephant population. PhD Thesis, University of Pretoria, Pretoria.

Whyte, I., van Aarde, R. \& Pimm, S.L. (1998). Managing the elephants of Kruger National Park. Anim. Conserv. 1, 77-83.

Wittemyer, G., Rasmussen, H.B. \& Douglas-Hamilton, I. (2007). Breeding phenology in relation to NDVI variability in free-ranging African elephant. Ecography 30, 42-50.

Young, K.D. \& van Aarde, R.J. (2010). Density as an explanatory variable of movements and calf recruitment in savannah elephants across southern Africa. J. Anim. Ecol. 79, 662673.

Young, K.D. \& van Aarde, R.J. (2011). Science and elephant management decisions in South Africa. Biol. Conserv. 144, 876-885.

Young, K.D., Ferreira, S.M. \& van Aarde, R.J. (2009). The influence of increasing population size and vegetation productivity on elephant distribution in the Kruger National Park. Austral Ecol. 34, 329-342. 